\title{
Peningkatan Kemampuan Menentukan Nilai Tempat Bilangan Menggunakan Media Gelas Warna Pada Peserta Didik Kelas I
}

\section{Dody Susilo}

Universitas Sebelas Maret

dodysusilo20@gmail.com

\section{Article History}

received 30/4/2021

\begin{abstract}
The objective of this research is to improve the capability of determine the place value of a number use of colored glass media in first grade students of primary school. This research is a classroom action research, As the subject is a first grade students of primary school Blangu 3. Data collection technique used observation techniques, tests, interviews, and documentation. Data analysis technique used was a comparative descriptive. The results of this research shows that there is an improvement for the capability of determine the place value of a number. This is evident an the initial conditions the classical completeness of $33.33 \%$. In first cycle the classical completeness of $73.33 \%$. and the second cycle the classical completeness of $86.67 \%$. these result indicate that the use of colored glass media can improvement for the capability of determine the place value of a number in first grade students of primary school.
\end{abstract}

Keywords: Number place value, color glass media

\section{Abstrak}

Tujuan penelitian ini adalah untuk meningkatkan kemampuan menentukan nilai tempat bilangan menggunakan media gelas warna pada peserta didik kelas I. Penelitian ini merupakan penelitian tindakan kelas (PTK). Subjek penelitian ini adalah peserta didik kelas I SDN Blangu 3. Teknik pengumpulan data menggunakan teknik tes, observasi, wawancara, dan dokumentasi. Teknik ananlisis data yang digunakan adalah model deskiptif komparatif. Hasil penelitian ini menunjukkan adanya peningkatan kemampuan menentukan nilai tempat bilangan Hal ini terbukti pada kondisi awal presentase ketuntasan klasikal 33,33\%. Siklus I presentase ketuntasan klasikal $73,33 \%$, dan siklus II ketuntasan klasikal $86.67 \%$. Hasil ini menunjukkan bahwa penggunaan media gelas warna dapat meningkatkan kemampuan menentukan nilai tempat bilangan pada peserta didik kelas I sekolah dasar.

Kata kunci: Nilai tempat bilangan, media gelas warna 


\section{PENDAHULUAN}

Penyelenggaraan proses pembelajaran yang bermakna, serta hasil belajar yang baik dan memuaskan, merupakan harapan orang tua peserta didik dan seluruh pihak yang terkait. Hasil belajar yang diharapkan adalah hasil belajar yang dapat dimanfaatkan oleh peserta didik dalam kehidupan sehari-hari. Agar tujuan pembelajaran ini dapat tercapai maka diperlukan keterlibatan guru dan peserta didik secara aktif dalam proses pembelajaran.

Fakta yang ada di lapangan menunjukan bahwa harapan ini belum bisa terwujud secara optimal. Masih banyak kendala untuk mewujudkan proses pembelajaran yang bermakna. Beberapa faktor yang mempengaruhi antara lain: peserta didik itu sendiri, muatan pelajaran, serta strategi guru dalam menyampaikan pembelajaran. Hal ini juga terjadi pada Pelajaran matematika.

Banyak peserta didik yang beranggapan Pelajaran matematika adalah pelajaran yang paling sulit dan membosankan serta menjadi momok bagi peserta didik. Peserta didik terkesan kurang tertarik pada pelajaran matematika, hal ini terlihat dari peserta didik yang kurang antusias dan pasif dalam mengikuti pembelajaran matematika. Akibatnya peserta didik kurang dapat memahami materi pelajaran secara mendalam.

Hal ini juga terjadi pada peserta didik kelas I SDN Blangu 3, dari hasil pengamatan dan wawancara dengan guru kelas I SDN Blangu 3, masih banyak peserta didik yang mengamali kesulitan dalam pembelajaran muatan pelajaran matematika. Khususnya pada mutan nilai tempat bilangan, peserta didik masih kesulitan memahami konsep nilai tempat bilangan. Hal ini dibuktikan dengan banyaknya peserta didik sering menulis lambang bilangan pada operasi hitung dari depan tanpa memperhatikan nilai tempat. Sehingga sering kali terjadi kesalahan dalam penjumlahan bilangan. Bahkah beberapa peserta didik masih mengalami kebingungan untuk menentukan puluhan maupun satuan dalam bilangan. Hal ini disebabkan karena proses pembelajaran yang kurang kondusif. Metode pembelajaran yang digunakan masih bersifat konvensional yaitu : ceramah tanya jawab dan pemberian tugas. Guru belum mengkaitkan muatan pelajaran dengan benda konkrit yang sering dijumpai peserta didik dalam kehidupan sehari-hari, serta belum memanfaatkan TPACK dalam pembelajaran.

Data yang diperoleh melalui wawancara dan observasi, tingkat keberhasilan Pembelajaran tergolong cukup rendah. Dari 15 peserta didik hanya 5 peserta didik $(33,33)$ yang dapat mengikuti pelajaran dengan baik, sisanya 10 peserta didik $(66,67)$ mengalami kesulitan. Fakta tersebut merupakan suatu indikasi bahwa proses pembelajaran yang telah dilaksanakan kurang berhasil dalam memberikan pemahaman konsep nilai tempat bilangan. Oleh karena itu pembelajaran pada muatan nilai tempat perlu ditingkatkan, karena jika tidak segera diatasi dapat berdampak pada rendahnya hasil belajar peserta didik. Selain itu juga akan berdampak pada kesalahan peserta didik dalam mengaplikasikannya dalam kehidupan sehari-hari. Mengingat konsep nilai tempat bilangan sangat berkaitan dengan penjumlahan yang sering terjadi dalam kehidupan sehari hari.

Gloria (2015: 53) mengemukakan bahwa Mathematics concept is an idea or mental impression, the content of which is primarily related to computation, quantitative relationship, systematic reasoning or structure or configuration. Hal ini dapat diartikan bahwa matematika adalah ide-ide yang umumnya berisikan perhitungan, hubungan kuantitatif, penalaran yang sistematis atau struktur konfigurasi. Sedangkan menurut soedjadi (dalam Herruman, 2017: 1) matematika memiliki objek tujuan yang abstrak, bertumpu pada kesepakatan, dan pola pikir yang deduktif. Oleh karena ke abstrakan inilah yang membuat matematika tidak mudah untuk dipelajari, terutama untuk usia anak SD yang masih berpola pikir konkret.

Hal ini sejalan dengan yang dikemukakan Herruman (2017: 1) siswa SD masih terikat dengan objek konkret yang dapat ditangkap oleh panca indera. Sedangkan 
menurut Karso $(2011,1.4)$ menyatakan bahwa anak usia SD sedang mengalami perkembangan pada tingkat berpikirnya. Tahap berpikir mereka masih belum formal, bahkan siswa di kelas rendah bukan tidak mungkin sebagian dari mereka berpikirnya masih berada pada tahapan pra konkret. Dalam pembelajaran matematika yang abstrak perlu segera diberikan penguatan, agar mengendap dan bertahan lama dalam memori siswa. Maka dari itu proses pembelajaran hendaknya menjembatani materi yang abstrak menjadi konkret, serta melibatkan peserta didik secara aktif dalam pembelajaran. Sehingga peserta didik akan lebih mudah untuk menangkap konsep matematika, dan akan tersimpan dalam ingatan peserta didik dengan baik. Berhubungan dengan hal tersebut, maka sebaiknya dalam pembelajaran harus mengkaitkan muatan dengan benda konkret, agar peserta didik mudah untuk memahami konsep matematika. Salah satu cara untuk membuat konsep matematika menjadi konkret adalah dengan penggunaan media pembelajaran yang tepat.

Media pembelajaran merupakan salah satu unsur yang memegang peranan penting dalam proses pembelajaran. Media merupakan penyampaian pesan dari pengirim pesan kepada penerima pesan, dapat dikatakan juga media merupakan wahana penyalur informasi atau penyalur pesan belajar (Rusman, 2017: 214). Sedangkan menurut sudjana (2019:2) media memiliki manfaat untuk menarik perhatian siswa sehingga dapat menumbuhkan motivasi belajar. Dari pendapat di atas ditarik kesimpulan bahwa penggunaan media pembelajaran akan sangat membantu keefektifan proses pembelajaran dalam penyampaian pesan dan isi pembelajaran. Media pembelajaran dapat mengubah konsep abstrak menjadi konkret. Penggunaan media pembelajaran juga dapat membangkitkan minat, motivasi serta rasa ingin tahu peserta didik.

Untuk mengatasi permasalahan rendahnya kemampuan menentukan nilai tempat bilangan pada peserta didik kelas I SDN Blangu 3, maka dalam pembelajaran dapat menggunakan media pembelajaran yang sesuai. Salah satu media pembelajaran yang dapat digunakan adalah media gelas warna. Gelas warna merupakan media yang dapat digunakan untuk menjelaskan konsep nilai tempat bilangan. Media gelas warna berbentuk gelas dengan dua warna yang berbeda. Salah satu warna mewakili nilai puluhan dan warna lainnya mewakili nilai satuan. Pada penilitian ini, peneliti mengambil gelas warna hijau sebagai puluhan dan gelas warna kuning sebagai satuan. Setiap gelas warna hijau yang mewakili nilai puluhan harus berisi 10 , dan untuk gelas warna kuning yang mewakili satuan setiap gelas hanya boleh diisi satu buah. Kemudian hitung jumlah gelas warna hijau yang terisi, untuk menentukan nilai puluhan dan hitung jumlah gelas warna kuning yang terisi untuk menentukan nilai satuan.

Penggunaan media gelas warna dalam proses pembelajaran akan mempermudah penanaman konsep nilai tempat yang abstrak menjadi konkret. Penggunaan media gelas warna dengan dua warna yang berbeda akan memudahkan peserta didik untuk menentukan nilai tempat bilangan asli. Dalam media gelas warna letak puluhan dan satuan berada pada gelas yang berbeda warna.

\section{METODE}

Penelitian ini adalah penelitian tindakan kelas, yang memiliki empat tahapan seperti yang dikemukakan Mulyasa (2010:11) yaitu, Tahap perencanaan (planning), Tahap pelaksanaan (acting), Tahap pengamatan (observing), Tahap Refleksi (reflecting). Penelitian ini dilakukan selama 6 bulan, mulai bulan januari sampai bulan juni. Subjek dalam penelitian ini adalah peserta didik kelas I SDN Blangu 3 yang berjumlah 15 peserta didik. sumber data pada penelitian ini berupa data primer yaitu guru kelas I dan peserta didik kelas I SDN Blangu 3, serta sumber data sekunder yaitu dokumen, foto, video RPP. Teknik pengumpulan data menggunakan teknik tes, observasi, wawancara, dan dokumentasi. Validitas yang digunakan berupa triangulasi 
sumber dan triangulasi teknik. Teknik analisis data berupa analisis deskriptif komparatif.

\section{HASIL DAN PEMBAHASAN}

Sebelum pelaksanaan tindakan, peneliti melakukan observasi, wawancara dan tes untuk mengetahui permasalahan yang terjadi dalam pembelajaran di kelas I. Berdasarkan hasil kegiatan tersebut, ditemukan terdapat permasalahan yaitu masih rendahnya kemampuan menentukan nilai tempat bilangan pada peserta didik kelas I SDN Blangu 3, hal ini terbukti dari sebagian besar nilai peserta didik masih dibawah KKM yaitu 70. Hasil dapat dilihat melalui tabel 1. Frekuensi nilai pratindakan

Tabel 1. Frekuensi Nilai Pratindakan

\begin{tabular}{cccccc}
\hline No & $\begin{array}{c}\text { Interval } \\
\text { kelas }\end{array}$ & $\begin{array}{c}\text { Frekuensi } \\
(\mathbf{f i})\end{array}$ & $\begin{array}{c}\text { Nilai } \\
\text { Tengah (xi) }\end{array}$ & fi.xi & $\begin{array}{c}\text { Presentase } \\
(\%)\end{array}$ \\
\hline 1 & $30-39$ & 2 & 34,5 & 69 & $13,33 \%$ \\
2 & $40-49$ & 3 & 44,5 & 133,5 & $20 \%$ \\
3 & $50-59$ & 3 & 54,5 & 163,5 & $20 \%$ \\
4 & $60-69$ & 2 & 64,5 & 129 & $13,33 \%$ \\
5 & $70-79$ & 4 & 74,5 & 298 & $26,67 \%$ \\
6 & $80-89$ & 1 & 84,5 & 84,5 & $6,67 \%$ \\
& Jumlah & 15 & 357 & 877,5 & 100 \\
\hline
\end{tabular}

Berdasarkan tabel 1. Frekuensi nilai pratindakan dapat diketahui bahwa nilai rata-rata kelas sebelum dilakukan tindakan yaitu 58,5 dengan peserta didik yang memperoleh nilai di atas KKM sebanyak 5 peserta didik atau 33,33\%, sedangkan sebanyak 10 peserta didik (66,67\%) memperoleh nilai dibawah KKM. Hal ini membuktikan bahwa kemampuan menentukan nilai tempat bilangan peserta didik kelas I SDN Blangu 3 masih rendah.

Pada siklus I setelah pembelajaran menggunakan media gelas warna, kemampuan menentukan nilai tempat bilangan peserta didik meningkat. Hal ini dapat dilihat pada tabel 2. Frekuensi nilai Siklus I sebagai berikut:

Tabel 2. Frekuensi Nilai Siklus 2

\begin{tabular}{cccccc}
\hline No & $\begin{array}{c}\text { Interval } \\
\text { kelas }\end{array}$ & $\begin{array}{c}\text { Frekuensi } \\
\text { (fi) }\end{array}$ & $\begin{array}{c}\text { Nilai } \\
\text { Tengah (xi) }\end{array}$ & fi.xi & $\begin{array}{c}\text { Presentase } \\
(\%)\end{array}$ \\
\cline { 4 - 6 } 1 & $40-49$ & 2 & 44,5 & 89 & $13,33 \%$ \\
2 & $50-59$ & 1 & 54,5 & 54.5 & $6,67 \%$ \\
3 & $60-69$ & 1 & 64,5 & 64,5 & $6,67 \%$ \\
4 & $70-79$ & 4 & 74,5 & 298 & $26,67 \%$ \\
5 & $80-89$ & 5 & 84,5 & 422,5 & $33,33 \%$ \\
6 & $90-99$ & 2 & 94,5 & 189 & $13,33 \%$ \\
& Jumlah & 15 & 417 & 1117,5 & 100 \\
& Nilai rata-rata $=1117,5: 15=74,5$ & \\
\hline
\end{tabular}

Berdasarkan tabel 2. Frekuensi nilai siklus I di atas, terjadi peningkatan pada siklus I. Pada siklus I peserta didik yang memperoleh nilai di atas KKM sebanyak 11 peserta didik atau $(73,33 \%)$ dan peserta didik yang memperoleh nilai di bawah KKM sebanyak 4 peserta didik $(26,67 \%)$ dengan nilai rata-rata kelas sebesar 74,5 .

Indikator kinerja pada penelitian ini adalah $80 \%$ peserta didik memperoleh nilai diatas $\mathrm{KKM} \geq 70$. Karena hasil pada siklus I belum mencapai indikator kinerja penelitian, sehingga dilakukan refleksi dan tindaklanjut pada siklus II. Adapun hasil 
penelitian pada siklus II dapat dilihat melalui Tabel 3. Frekuensi Nilai Siklus II sebagai berikut:

Tabel 3. Frekuensi Nilai Siklus II

\begin{tabular}{cccccc}
\hline No & $\begin{array}{c}\text { Interval } \\
\text { kelas }\end{array}$ & $\begin{array}{c}\text { Frekuensi } \\
\text { (fi) }\end{array}$ & $\begin{array}{c}\text { Nilai } \\
\text { Tengah (xi) }\end{array}$ & fi.xi & $\begin{array}{c}\text { Presentase } \\
(\%)\end{array}$ \\
\hline 1 & $41-50$ & 1 & 45,5 & 45,5 & $6,67 \%$ \\
2 & $51-60$ & 1 & 55,5 & 55,5 & $6,67 \%$ \\
3 & $61-70$ & 4 & 65,5 & 262 & $26,67 \%$ \\
4 & $71-80$ & 5 & 75,5 & 377,5 & $33,33 \%$ \\
5 & $81-90$ & 2 & 85,5 & 171 & $13,33 \%$ \\
6 & $91-100$ & 2 & 95,5 & 191 & $13,33 \%$ \\
& Jumlah & 15 & 417 & 1170,5 & 100 \\
& Nilai rata-rata $=1162,5: 15=77.5$ & \\
\hline
\end{tabular}

Berdasarkan tabel 3. Frekuensi nilai siklus II di atas didapati bahwa adanya peningkatan ketuntasan klasikal pada siklus II. Hal ini dibuktikan dengan peserta didik yang memperoleh nilai diatas KKM sebanyak 13 peserta didik $(86,67 \%)$ dan peserta didik yang memperoleh nilai dibawah KKM sebanyak 2 peserta didik (13,33\%) dengan nilai rata-rata kelas 77,5 . Hasil penelitian pada siklus II telah memenuhi atau mencapai target atau indikator kinerja yang telah ditetapkan. Oleh karena itu peneliti mengakhiri tindakan dalam penelitian ini sampai siklus II.

Berdasarkan hasil pengamatan dan analisis data yang telah dilakukan, dapat dinyatakan bahwa pembelajaran dengan menggunakan media gelas warna dapat meningkatkan kemampuan menentukan nilai tempat bilangan. Hal tersebut dapat dibuktikan dengan perbandingan hasil sebelum dan sesudah tindakan, yang dapat dilihat pada tabel 4. Data perkembangan nilai sebagai berikut:

Tabel 4. Data perkembangan Nilai

\begin{tabular}{clccc}
\hline No & keterangan & pratindakan & Siklus I & Siklus II \\
\hline 1 & Nilai Terendah & 30 & 40 & 50 \\
2 & Nilai Tertinggi & 80 & 90 & 100 \\
3 & Nilai Rata-rata & 58,5 & 74,5 & 77,5 \\
4 & Ketuntasan (\%) & 33,33 & 73,33 & 86,67 \\
\hline
\end{tabular}

Berdasarkan tabel 4 di atas dapat dilihat bahwa kemampuan menentukan nilai tempat bilangan peserta didik kelas I SDN Blangu 3 mengalami peningkatan mulai dari pratindakan, siklus I dan siklus II. Nilai terendah pada pratindakan adalah 30 , kemudian meningkat menjadi 40 pada siklus I, kemudian meningkat kembali menjadi 50 pada siklus II. Nilai tertinggi pada pratindakan adalah 80 , kemudian meningkat menjadi 90 pada siklus I, kemudian meningkat kembali menjadi 100 pada siklus II, nilai rata-rata pada pratindakan 58,5 meningkat menjadi 74,5 pada siklus I kemudian meningkat menjadi 77,5 pada siklus II dan ketuntasan klasikal yang awalnya $33,33 \%$ pada pratindakan, meningkat menjadi $73,33 \%$ pada siklus I dan kembali meningkat menjadi $86,67 \%$ pada siklus II.

Pencapaian kompetensi belajar ini menunjukkan bahwa penerapan media pembelajaran media gelas warna dapat meningkatkan kemampuan nilai tempat bilangan, karena media gelas warna dapat digunakan sebagai sarana untuk menyalurkan pesan, hal ini sesuai dengan pendapat suryani (2012:136) yang 
menyatakan media yang digunakan dalam pembelajaran, yaitu meliputi alat bantu guru dalam mengajar serta sarana pembawa pesan dari sumber belajar ke penerima pesan belajar. Selain itu penggunaan media gelas warna dapat memperjelas konsep nilai tempat bilangan, karena menjadi lebih konkret. Hal ini sejalan dengan pendapat Daryanto (2011: 4) yang mengemukakan bahwa salah satu manfaat media adalah untuk memperjelas pesan agar tidak terlalu verbalistis.

Hasil penelitian ini berbanding lurus dengan penelitian-penelitian sebelumnya yang menjadi rujukan seperti yang dilakukan Tomi Sulistio Budi dan Reza Ika Savitri yang secara garis besar menyimpulkan bahwa kemampuan menentukan nilai tempat bilangan dapat ditingkatkan dengan penggunaan media pembelajaran. Pertama Penelitian yang dilakukan oleh Tomi Sulistyo Budi dengan judul "Peningkatan kemampuan memahami nilai tempat dengan media abakus pada siswa kelas II SD Negeri Bukuran 2 Kecamatan Kalijambe Kabupaten Sragen tahun pelajaran 2009/2010" pada penelitian tersebut kemampuan memahami nilai tempat dapat ditingkatkan dengan media pelajaran abakus. kemudian penelitian Reza Ika Savitri dengan judul "Peningkatan Pemahaman Konsep Nilai Tempat Bilangan Melalui Media Kantung Biji Bilangan Pada Siswa Kelas I-A Sekolah Dasar". Pada penelitian tersebut pemahaman konsep nilai tempat bilangan dapat ditingkatkan dengan media kanjung biji bilangan.

\section{SIMPULAN}

Berdasarkan hasil penelitian yang telah dilakukan dalam dua siklus dengan menggunakan media gelas warna dalam materi nilai tempat bilangan pada peserta didik kelas I SDN Blangu 3 dapat ditarik kesimpulan bahwa penggunaan media gelas warna dapat meningkatkan kemampuan menentukan nilai tempat bilangan pada peserta didik kelas I SDN Blangu 3 Tahun Pelajaran 2020/2021. Hal ini dapat dibuktikan dengan meningkatnya nilai rata-rata dan ketuntasan klasikal pada setiap siklusnya, yaitu pada pratindakan nilai rata-rata 58,5 siklus I nilai rata-rata peserta didik meningkat menjadi 74,5 , dan siklus II nilai rata-rata peserta didik meningkat lagi menjadi 77,5 . Sedangkan ketuntasan klasikal pada pratindakan yaitu sebesar 33,33\% atau 5 peserta didik dari 15 peserta didik, siklus I ketuntasan klasikal meningkat menjadi $73,33 \%$ atau 11 peserta didik dari 15 peserta didik dan siklus II ketuntasan klasikal meningkat lagi menjadi $86,67 \%$ atau 13 peserta didik.

\section{DAFTAR PUSTAKA}

Daryanto. (2011). Media Pembelajaran. Bandung: Sarana Tutorial Nurani Sejahtera Gloria charina. (2015). Mathematical Competence And Performance In Geometry Of High School Students. Diperoleh pada tanggal 1 Februari 2016 dari http: //ejournalofsciences.org/archive/vol5no2/vol5no2_4.pdf

Heruman. (2017). Model Pembelajaran Matematika. Bandung: Remaja Rosdakarya

Karso, dkk. (2011). pendidikan matematika. Jakarta: universitas terbuka

Mulyasa, (2010). Kurikulum Berbasis Kompetensi. Bandung: Remaja Rosdakarya

Reza Ika Savitri. 2019. Peningkatan Pemahaman Konsep Nilai Tempat Bilangan Melalui Media Kantung Biji Bilangan Pada Siswa Kelas I-A Sekolah Dasar. UMM

Rusman. (2017). Belajar dan Pembelajaran. Jakarta: Kencana

Sudjana, Nana dan Ahmad Rivai. (2019). Media Pengajaran. Bandung; Sinar Baru Algensindo

Suryani, nunuk dan leo agung. (2012). Strategi Belajar Mengajar. Yogyakarta: Ombak

Tomi Sulistyo Budi. (2011). Peningkatan kemampuan memahami nilai tempat dengan media abakus pada siswa kelas II SD Negeri Bukuran 2 Kecamatan Kalijambe Kabupaten Sragen tahun pelajaran 2009/2010. UNS 